Provided for non-commercial research and education use. Not for reproduction, distribution or commercial use.

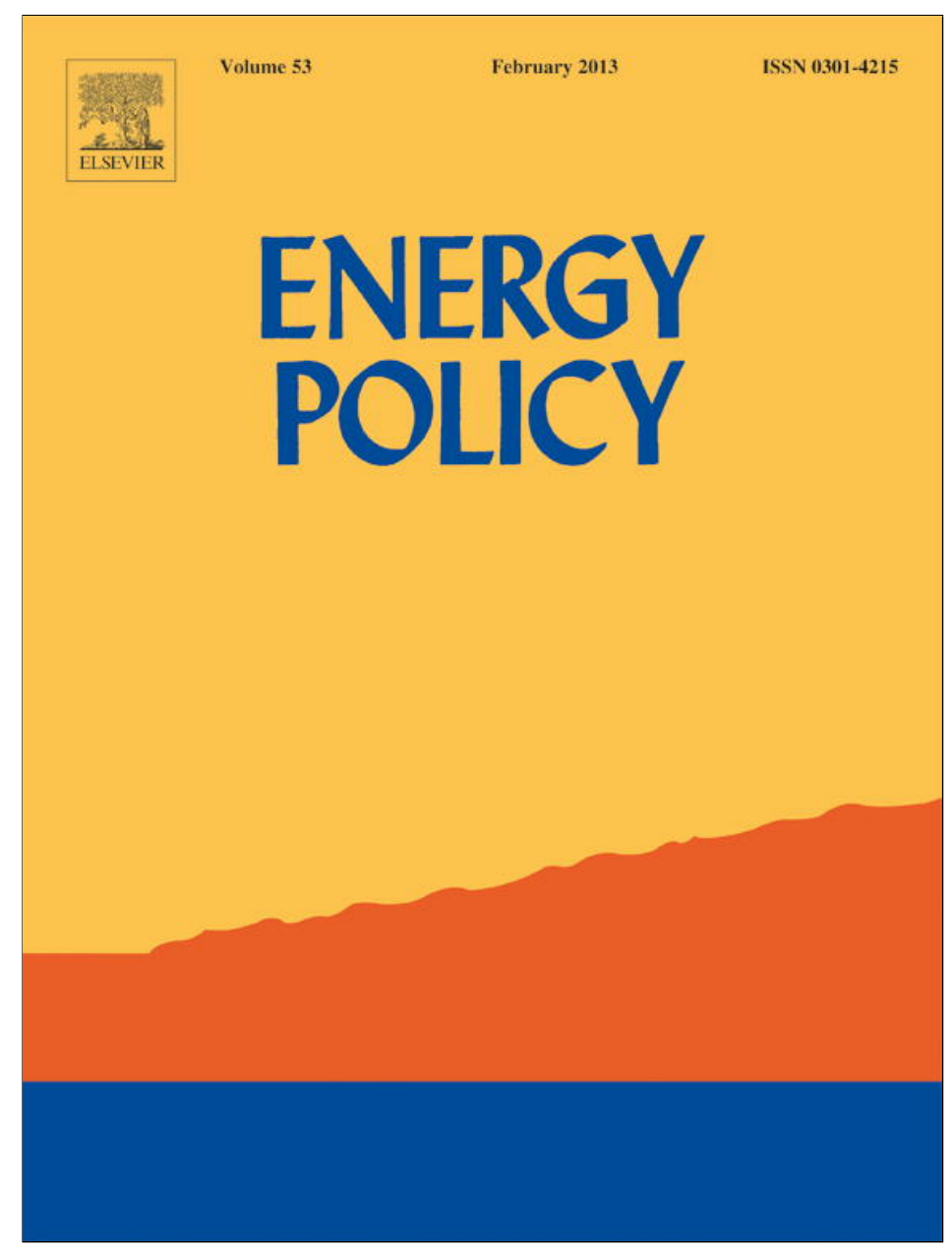

This article appeared in a journal published by Elsevier. The attached copy is furnished to the author for internal non-commercial research and education use, including for instruction at the authors institution and sharing with colleagues.

Other uses, including reproduction and distribution, or selling or licensing copies, or posting to personal, institutional or third party websites are prohibited.

In most cases authors are permitted to post their version of the article (e.g. in Word or Tex form) to their personal website or institutional repository. Authors requiring further information regarding Elsevier's archiving and manuscript policies are encouraged to visit:

http://www.elsevier.com/copyright 


\title{
Whatever the customer wants, the customer gets? Exploring the gap between consumer preferences and default electricity products in Germany ${ }^{2}$
}

\author{
Josef Kaenzig, Stefanie Lena Heinzle, Rolf Wüstenhagen* \\ Institute for Economy and the Environment, University of St. Gallen, Tigerbergstrasse 2, 9000 St. Gallen, Switzerland
}

H I G H L I G H T S

- Study is based on 4968 experimental choices made by 414 German retail consumers.

- Apart from price, the electricity mix is the most important product attribute.

- Majority of consumers prefer nuclear-free electricity.

- Respondents are willing to pay a premium for green electricity.

- German default electricity mix does not correspond to current customer preferences.

\section{A R T I C L E I N F O}

\section{Article history:}

Received 15 April 2011

Accepted 29 October 2012

Available online 21 November 2012

\section{Keywords:}

Green power marketing

Discrete choice experiments

Product design

\begin{abstract}
A B S T R A C T
In liberalized electricity markets, residential customers can choose their preferred provider and select among a variety of different electricity products, including green power options. Successful product design and marketing strategies for green electricity may provide electricity providers with a competitive advantage, while at the same time contributing to energy policy objectives. This requires, however, a thorough understanding of customer preferences. We investigate the relative importance of different product attributes in creating customer value, and find that price and electricity mix are the two most important attributes. The German electricity customers we surveyed in 2009 expressed an implicit willingness to pay a premium of about $16 \%$ for electricity from renewable sources. We conclude that consumers are willing to pay a significant price premium for an upgrade from the current default electricity mix in Germany to a more environmentally friendly default electricity mix, and discuss implications for marketing strategy and energy policy. Our findings are based on a dataset of 4968 experimental choices made by 414 German residential consumers, collected in a stated preference survey.
\end{abstract}

(c) 2012 Elsevier Ltd. All rights reserved.

\section{Introduction}

Prior to the opening of energy markets for competition, most consumers were served by a monopoly utility. Electricity market liberalization gives customers the possibility to choose products that best match their preferences. Many countries in Europe, North America and the Asia-Pacific region have liberalized their electricity markets in recent years. Customers now have a choice between competing suppliers offering a range of products, and it is becoming increasingly valuable for electric utilities and other power marketers to understand customer preferences, decision-

\footnotetext{
Parts of the text in this article have initially been drawn from the PhD dissertation of one of the co-authors who reports on a similar study conducted in Switzerland (Kaenzig, 2010; Burkhalter et al., 2009). The present paper is based on an entirely new dataset of German consumers.

* Corresponding author. Tel.: +4171 2242587; fax: +41712242722.

E-mail address: rolf.wuestenhagen@unisg.ch (R. Wüstenhagen).
}

making processes, and barriers to switching behavior. However, many customers are still reluctant to actively choose a new power provider as well as to opt out of their default option.

As illustrated by the literature review in the following section, there are many studies showing that consumers have positive attitudes towards renewable energy and a majority of consumers report a willingness to buy electricity generated from renewable energy sources, even at a premium. Nevertheless, the high level of reported willingness to pay (WTP) is often poorly reflected in actual market shares of green electricity products. Although many consumers express environmental attitudes, there is still only a rather small segment of consumers who make the leap from interest to purchase.

Behavioral economics provides possible explanations on why consumers do not easily adopt environmental innovation, such as green electricity, despite their positive attitudes towards the environment. An important area of research in behavioral economics implies that consumers' behavior can be influenced by simply 
changing the default option (Thaler and Sunstein, 2008). The default option is what consumers receive if they do not explicitly ask for another product (Brown and Krishna, 2004). Rational choice, contrary to behavioral economics, would imply that individual decision-making is not influenced by the default. However, the power of defaults has been demonstrated in different fields, ranging from organ donorship through retirement funds to car sales (Goldstein et al., 2008; Johnson and Goldstein, 2003; Polak et al., 2008). Anderson (2003) and Sunstein and Thaler (2003) have shown that consumers tend to be reluctant to selecting an alternative to the default option. Electricity consumers may be no exception, but apart from a few natural experiments ${ }^{1}$ and two laboratory experiments (Pichert and Katsikopoulos, 2008), there is a scarcity of empirical evidence so far about the specific influence of defaults on the choice of electricity products.

This study addresses whether specific characteristics of electricity products offered as the default (i.e. the standard electricity option the consumers would receive from their electric utility if they do not actively select an alternative) in Germany match the preferences of private consumers. To determine customers' preferred electricity product, we conducted computer-assisted personal interviews with 414 German residential electricity consumers, leading to a dataset of 4968 choices. We determined customer preferences and the importance of individual product attributes in consumer choice. The goal of this study is to contribute to filling research gaps by (1) analyzing German private-household customers' preferences for a large number of specific attributes of electricity products, (2) comparing customer preferences for electricity products to the average default electricity mix, (3) determining the preferred energy sources for electricity production, and (4) discussing implications for policymakers, power marketers, and utilities.

This article proceeds as follows: Section 2 reviews the existing literature. Section 3 presents our main hypothesis. Section 4 describes the methodological approach and the design of the survey based on choice experiments. Section 5 presents the empirical results, including the part-worth utility estimations based on a hierarchical Bayes model, and an analysis of the preferred energy sources. Section 6 presents concluding remarks and avenues for future research.

\section{Customer choice and default electricity mix in liberalized electricity markets}

Purchase decisions in competitive electricity markets can be disaggregated into several phases: problem recognition, information search on products and power providers, evaluation of alternatives, selection, and purchase. The search and the selection of a new power product or a new power provider can be initiated and motivated by various factors, which has been investigated in several stated preference surveys. Watson et al. (2002) determined price, environmentally sound electricity production, and incentives for new customers as the most important motives for switching power providers. Rowlands et al. (2004) identified price, reliability of power supply, and service quality as the most important factors when choosing an electricity company, followed by environmental aspects, reputation of the power provider, and the location of the electricity generation. A study by Goett et al. (2000) analyzed preferences from small and medium business customers for 40

\footnotetext{
${ }^{1}$ For example, the municipal utility of the City of St. Gallen in Switzerland has recently changed to a green default and found that $72 \%$ of its residential customers stayed with the new default, while $10 \%$ decided to actively downgrade to a cheaper product, and $18 \%$ actively upgraded to one of two pure green power options (Graf, 2012).
}

attributes of electricity products. Roe et al. (2001) and Bird et al. (2002) analyzed preferences of private household customers and found that they are willing to pay a higher price for green power than for the standard electricity mix. Customers prefer renewable energy sources (Borchers et al., 2007; Farhar, 1999; Kaenzig and Wüstenhagen, 2008; Mozumder et al. 2011) and many studies show that a majority of consumers report a willingness to buy electricity generated from renewable energy sources, even at a premium (Gerpott and Mahmudova, 2009; Hansla, 2011; Litvine and Wüstenhagen, 2011; Menegaki, 2012; Menges et al., 2004; Menges et al., 2005; Mewton and Cacho, 2011; Nomura and Akai, 2004; Oliver et al., 2011; Susaeta et al., 2011). The relative price premium customers are willing to pay varies significantly between studies. Possible explanations are differences in framing of the offer, as well as differences in household income and culture between countries. But according to all studies, respondents are willing to pay a price premium for green power products.

It has also been found that time-consuming and complicated purchase processes, complex products, non-transparent price models, as well as long-term contracts inhibit switching behavior (OECD, 2008; Rommel and Meyerhoff, 2009). Customer loyalty is considered to be significantly affected by customer satisfaction and the perception of switching costs (García-Acebrón et al., 2010; Hartmann and Apaolaza-Ibáñez, 2007). In many European countries with liberalized electricity markets and also in countries where green electricity products are widely available for private household customers, only a small share of consumers actively switched to green power products (Energie and Management, 2010; Wüstenhagen et al., 2003). Most consumers stay with their power provider and the product they are used to, and hereby avoid transaction costs.

The power of defaults provides an explanation as to why individuals stay with products they are used to, even though there may be alternatives on the market which would meet their preferences better. As default products are often used as reference products, consumers may see opting-out of the default as risky compared to the perceived safety of the default mix. Remaining with the default alternative avoids risk. Status quo biases (Kahneman et al., 1991; Samuelson and Zeckhauser, 1988) also heavily influence consumer behavior in the context of low involvement products such as electricity. Johnson and Goldstein (2003) have explained the effect of how defaults influence individuals' decision-making processes in different ways. On the one hand, defaults chosen by electricity providers can be perceived as implicit government recommendations. On the other hand, making an active decision requires physical effort and involves transaction cost (Samuelson and Zeckhauser, 1988). In connection to this, one explanation is the existence of human inertia. Especially when people have to deal with a complex decision-making process, they tend not to make any decision at all or delay it to a later point in time. This problem of inertia and procrastination is related to the concept of "bounded self-control" (Mullainathan and Thaler, 2000). Bounded self-control describes individuals who have the right intentions or beliefs but prove to be limited in their capacity or lack the willpower to execute their intentions to change behavior. Thus, the existence of inertia also explains the fact that default rules tend to be "sticky" (Thaler and Sunstein, 2003).

Pichert and Katsikopoulos (2008) present first empirical evidence showing that these cognitive biases and mechanisms also hold for default electricity mixes. With two laboratory experiments among 65 students and persons younger than 35, they showed that participants are more likely to choose a green power option when it is presented as the default product than when it is presented as an alternative. Most of the respondents would stay with the default electricity mix even if it costs more 
than the cheapest electricity mix. They also show that the willingness to accept an imposed price premium for green power in the default electricity mix is higher than the willingness to pay (WTP) for the same green electricity mix when customers have to actively choose and order. This implies that once a green default is established, people are either reluctant to move away from this reference point or expect a relatively large incentive to do so.

\section{Hypothesis development and relevance of this research}

In liberalized markets, customers can choose from a range of electricity providers and products. It is possible to choose almost any mix of renewable, fossil and nuclear power. As discussed in the previous section, many studies show that customers prefer renewable energy sources and most customers state a positive WTP for green power products. However, in contrast to those stated preferences of their customers, most utilities in Germany and other countries continue to supply a majority of non-renewable energy. It may therefore be surprising that only a small share of customers actually switch to green power. There are two potential explanations for this: either previous research measuring WTP for green electricity has missed out on important other attributes of electricity products, and hence the apparent difference between consumer preferences and default products has been overstated. Or there is indeed a mismatch between what customers want and what they get, suggesting that the only reasons they stick to their current supply are the transaction costs and cognitive barriers that prevent them from opting-out of the default. In order to solve this puzzle, what we need to know is which product attributes, and more importantly which attribute levels, are really important to customers. Choice experiments with customers choosing between realistic electricity products allow determining preferences for specific product attributes and attribute levels. Based on these stated preferences, we can then compute their implicit WTP for each attribute level in comparison to the default attribute level. We are particularly interested in understanding the average WTP for different levels of the attribute 'electricity mix' relative to the current default mix. This allows testing the following hypothesis. Hypothesis: Costumers are willing to pay a significant price premium for an upgrade from the current default electricity mix in Germany to a more environmentally friendly electricity mix.

If the hypothesis could be confirmed, this would have important implications for policymakers and power marketers. From a policy perspective, a mismatch between customer preferences and current product offerings would suggest that introducing a new default product priced at or below stated WTP would simultaneously increase customer value and contribute to the public good. From a marketing perspective, a confirmation of our hypothesis would translate into the identification of unmet customer needs, and therefore either indicate new opportunities for competitive suppliers, or ring an alarm bell from an incumbent utility's perspective. It is therefore important to regularly assess consumer preferences and to test the above-mentioned hypothesis. The results presented in this study go beyond providing the basis for testing the hypothesis, in that they also provide in-depth insights into consumer preferences for electricity products and a wide range of attributes.

There are few publications assessing consumer preferences for specific attribute levels of electricity products, especially outside of the U.S. As stated by Goldstein et al. (2008, p. 104), 'it takes careful research and experimentation to align defaults with both the company's and customers' long-term interests. Firms that manage defaults strategically and ethically can expect to be paid back with loyalty and trust'. This article contributes to such careful research and experimentation for the electricity sector by investigating consumer preferences.

\section{Design of study and methodological approach}

To determine customer preferences for specific attributes of electricity products, we chose a stated preference survey approach including a choice experiment with residential customers, which allows assessing customer preferences with hypothetical, yet realistic product purchase decisions. A stated preference approach is based on behavioral intentions and responses to hypothetical choice situations, while a revealed preference approach is based on actual behavior (Ben-Akiva et al., 1994). Choice experiments allow for the simulation of choice situations for which there is only limited data on actual behavior and market data available. Given that there is still a high level of inertia in the German retail electricity market, green power customer numbers have only recently started to exhibit significant growth. Also, a revealed preference approach working with actual purchasing decisions would have faced challenges in terms of getting a sufficiently detailed dataset of product attributes considered in consumer choices. A stated preference approach also allows determining customer preferences for various product attributes in a controlled experimental setting, and makes it possible to test consumer reactions to products that are not yet available on the market.

\subsection{Choice experiments and conjoint analysis to measure customer preferences}

Choice experiments and conjoint analysis belong to the family of conjoint measurement methods. Conjoint measurement is an important achievement of marketing research emerging over the last 40 years (Gustafsson et al., 2007; Netzer et al., 2008; Simon, 2008). A very important field of application for conjoint measurement is product design. It answers the question of how to design a product to best satisfy market demand. Conjoint measurement determines the contribution of attributes to the total utility of a product. This research is based on stated preference surveys (choice experiments) to indirectly determine the importance of product characteristics on consumer decision-making. In choice experiments, the information flow can be controlled and it is possible to provide information to respondents in order to anticipate and simulate specific choice contexts or certain stages of market maturity in a realistic way. This is particularly interesting for the analysis of consumer preferences regarding new products or product features where limited market data is available (Louviere et al., 2003). Another advantage of conjoint measurement over selfexplicated approaches is the lower chance of receiving only socially accepted responses (Gustafsson et al., 2007).

For the analysis of discrete choice data collected in choice experiments, different methods exist. The latest methods are based on the hierarchical Bayes estimations (Allenby et al., 2004; Orme, 2007; Rossi and Allenby, 2003; Teichert, 2001) or random coefficient choice models. Within a Bayesian framework, the distribution of part-worths (coefficients or utility values) across the population is estimated and combined with the information on individuals' choices to derive posterior or conditional estimates of the individuals' values ${ }^{2}$. Revelt and Train (1999), Huber and Train (2001), and Scarpa et al. (2008) show that results from hierarchical Bayes estimation and mixed logit estimations (random coefficient estimations) are very similar. The importance of hierarchical Bayes estimations for quantitative marketing approaches is steadily increasing (Allenby et al., 2004; Rossi and Allenby, 2003). With hierarchical Bayes

\footnotetext{
${ }^{2}$ See Rossi and Allenby, 2003 and Huber and Train (2001) for a more detailed discussion of hierarchical Bayes modeling.
} 
estimations, it is possible to determine individual part-worth utilities to assess heterogeneity among customer segments. This is an advantage in comparison to traditional conjoint approaches based on aggregated preferences measures.

The hierarchical Bayes model consists of two levels: (1) at the higher level, individuals' part-worth utilities are described by a multivariate normal distribution; (2) at the lower level it is assumed that, given an individual's part-worth utilities, his probabilities of choosing particular alternatives follow a multinomial logit model (Johnson, 2000; Sawtooth Software, 2009).

A multivariate normal distribution is characterized by a vector of means and a matrix of variances and covariances:

$\beta_{i} \approx$ Normal $(\alpha, D)$

where $\beta_{i}$ is a vector of part worth utilities of the $i$ th individual; $\alpha$ a vector of means of the distribution of individuals' part-worth utilities; and $D$ a matrix of variances and covariances of the distribution of part-worth utilities across individuals.

At the individual level (2), the utility $u_{k}$ that the individual $i$ ascribes to the $k$ th alternative is defined as $u_{k}=x_{k}{ }^{\prime} \beta i$. The probability that individual $i$ chooses the $k$ th alternative in a given choice task therefore is

$p_{k}=\frac{\exp \left(x_{k}^{\prime} \beta_{i}\right)}{\sum_{j} \exp \left(x_{j}^{\prime} \beta_{i}\right)}$

where $x_{j}$ is a vector of attribute values describing the $j$ th alternative in that choice task.

The parameters to be estimated are the vectors $\beta_{i}$ (part-worth utilities per individual) and $\alpha$ (means of the distribution of partworth utilities per individual), as well as the matrix $D$ (variances and covariances of that distribution). The estimation of the partworth vector is done by an iterative process using Markov Chain Monte Carlo, which is a numerical method for computing integrals (Rossi et al., 2005).

\subsection{Selection of decision-relevant product attributes}

Relevant product attributes were selected based on an extensive literature research carried out for a study conducted by Burkhalter et al. (2009) in Switzerland. Based on further literature review and expert interviews, the attributes were adapted to the German market. When choosing attribute levels, the following criteria were considered: influence on the purchase decision, practicability of the levels, attribute alignability (Herrmann et al., 2009), as well as their correspondence to actual products offered in the German electricity market. The attributes and levels that were used for the choice experiments are listed in Table 1.

The different electricity mixes serve two purposes. On the one hand they represent a continuum from "brown power" based on non-renewable resources to green electricity offerings based partly or purely on renewable energy. Mix 2 represents the electricity mix offered as the default in Germany at the time of conducting the study, which consists of approximately $85 \%$ nonrenewable resources (hard coal, lignite and nuclear). Mix 1 represents the same mix as Mix 2, but replaces the $15 \%$ renewable energy in the default by electricity from unknown sources. Mix 3 represents the possibility of phasing out nuclear power plants and replacing them with natural gas fired plants, a scenario that had already been debated when we conducted the survey in 2009 and has gained further relevance in the aftermath of the 2011 Fukushima accident. Mix 4 and Mix 5 only contain electricity produced from renewable energy sources. While Mix 4 uses a blend of different renewable energy sources, Mix 5 is purely based on wind power.

The levels of the attribute power provider reflect the range of suppliers, from small local to large national players. This will allow assessing how important it is for residential customers that the electricity company is based locally. Along similar lines, the attribute location of electricity generation shows varying levels of geographic proximity in terms of where power is produced, testing whether consumers prefer regional or domestic electricity generation over imports from other countries. The levels of the attribute monthly electricity costs allow for estimating customers' implicit willingness to pay for the different product attributes.

The levels of the attribute certification include the three ecolabels for electricity that actually exist in Germany, plus the option of no certification. The attribute price guarantee tries to identify how much value consumers place on price stability. Using the attribute cancellation period, we can determine how long residential customers are willing to commit to their electricity providers.

For this study, the attributes and levels were presented using a full-profile design. This means that products were shown together with all their attributes at the same time in each of the choice

Table 1

Choice experiment design: attributes and levels.

\begin{tabular}{|c|c|c|c|c|c|}
\hline \multirow[t]{2}{*}{ Attribute } & \multicolumn{5}{|l|}{ Attribute levels } \\
\hline & Level 1 & Level 2 & Level 3 & Level 4 & Level 5 \\
\hline Power provider & $\begin{array}{l}\text { Major national } \\
\text { provider }\end{array}$ & Medium sized regional provider & Municipal utility & $\begin{array}{l}\text { Independent power } \\
\text { marketer }\end{array}$ & \\
\hline $\begin{array}{l}\text { Location of } \\
\text { electricity } \\
\text { generation }\end{array}$ & In the region & In Germany & In Switzerland & In Eastern Europe & \\
\hline $\begin{array}{l}\text { Monthly electricity } \\
\text { cost }\end{array}$ & 50 Euro & 55 Euro & 60 Euro & 65 Euro & 70 Euro \\
\hline $\begin{array}{l}\text { Certification (Eco- } \\
\text { Label) }\end{array}$ & ok power & TüV & Grüner Strom Label & -(no certification) & \\
\hline Price guarantee & None & 6 months & 12 months & 24 months & \\
\hline Cancellation period & Monthly & Quarterly & Semi-yearly & Yearly & \\
\hline Electricity mix & $\begin{array}{l}60 \% \text { coal, } 25 \% \text { nuclear, } \\
15 \% \text { origin unknown }\end{array}$ & $\begin{array}{l}60 \% \text { coal, } 25 \% \text { nuclear, } 5 \% \text { water, } \\
5 \% \text { wind, } 5 \% \text { biomass }\end{array}$ & $\begin{array}{l}60 \% \text { coal, } 25 \% \text { gas, } 5 \% \text { water, } \\
5 \% \text { wind, } 5 \% \text { biomass }\end{array}$ & $\begin{array}{l}50 \% \text { wind, } 30 \% \text { water, } \\
15 \% \text { biomass, } 5 \% \text { solar }\end{array}$ & $100 \%$ wind \\
\hline a & Mix 1: (“Brown power") & Mix 2: (“Default”) & Mix 3: (“No nuclear”) & Mix 4: (“Green power mix”) & Mix 5: ("Pure wind") \\
\hline
\end{tabular}

a Labels for electricity mixes ("brown power", "no nuclear" etc.) are used for illustrative purposes here only and had not been included in the original survey instrument. Instead, respondents were exposed to the detailed percentages of ingredients as indicated in Table 1. 


\begin{tabular}{|c|c|c|c|}
\hline \multicolumn{4}{|c|}{$\begin{array}{l}\text { If you had to choose between the following electricity products, which one would you } \\
\text { most likely choose? (Please click on the preferred product). }\end{array}$} \\
\hline Electricity mix & $\begin{array}{l}60 \% \text { coal, } \\
25 \% \text { nuclear, } \\
5 \% \text { water, } \\
5 \% \text { wind, } \\
5 \% \text { biomass }\end{array}$ & $\begin{array}{l}60 \% \text { coal, } \\
25 \% \text { gas, } \\
5 \% \text { water, } \\
5 \% \text { wind, } \\
5 \% \text { biomass }\end{array}$ & $100 \%$ wind \\
\hline Power provider & Municipal utility & $\begin{array}{l}\text { Medium sized, } \\
\text { regional power } \\
\text { provider }\end{array}$ & $\begin{array}{l}\text { Major, national } \\
\text { provider }\end{array}$ \\
\hline $\begin{array}{l}\text { Location of the } \\
\text { electricity generation }\end{array}$ & In the region & In Germany & In Eastern Europe \\
\hline Monthly electricity costs & $€ 50$ & $€ 60$ & $€ 70$ \\
\hline Certification & - & TÜV & ok power \\
\hline Price guarantee & None & 6 months & 12 months \\
\hline Cancelation period & Monthly & Semi-yearly & Yearly \\
\hline
\end{tabular}

Fig. 1. Sample choice task (translated from German).

tasks in order to get as close to a real-life decision-making situation as possible. Every survey participant was given 12 choice tasks to complete and each choice task included three randomly-generated product alternatives. A sample choice task is shown in Fig. 1.

\subsection{Method of data collection and dataset}

The target population of the study consisted of residential electricity customers in Germany. The sample was drawn by quota sampling, taking into account distribution of the target population by state (Bundesland), city size, household size, and sex. This is a standard procedure to draw representative samples in professional market research. The respondents were recruited by a professional marketing research company (GfK), who conducted computer assisted personal interviews (CAPI) in June 2009. The interviewers continuously built the sample until the target size of at least 400 customers was reached, and iterative rebalancing of the recruiting strategy was applied to make sure that the sample met the predefined criteria for representativeness. Given this recruitment strategy, we are unable to report on a final response rate, i.e., the percentage of respondents that actually took part in our survey in comparison to the total number of potential interviewees approached by the market research company. Therefore, a certain non-response bias might affect the representativeness of the sample; but as described below and in Table A1 in the Appendix, the sample of this survey corresponds very well to German electricity customers. In total, 414 German customers conducted 12 choice tasks each, leading to a total of 4968 observations. In order to be eligible for the survey, the respondents had to confirm that they were involved in their households' energy related decisions.

In the absence of specific data on the structure of German residential electricity customers, we assess representativeness of the sample by comparing to the overall German population (German Federal Statistics Office, 2009a, 2009b, 2009c). Except for two out of nine demographic characteristics, namely age and (self-declared) level of education, the sample is representative of the German population. The youngest population group consisting of those that are between the ages of 15 and 24 is underrepresented compared to the general population (2.7\% vs. $13.4 \%$ ). However, due to the relatively low number of young people with own households, it is reasonable to assume that they form a smaller proportion of electricity customers than in the entire
German population. Also those over the age of 65 seem to be underrepresented at first glance ( $16.4 \%$ vs. $23.3 \%)$. This may again be related to the fact that a large number of elderly people no longer pay their own electricity bills because they live with other family members or in retirement homes. No significant differences occur between our sample and the overall German population with regard to all other demographic characteristics: gender, monthly net income of household, city size, household size, region, civil status, and property ownership situation.

\section{Results: empirical findings}

In this section the detailed results of the choice experiment and the additional survey questions are presented. They encompass primarily the presentation of the average utility values of the individual attribute levels and the importance of the attributes to the product selection decisions made by the survey participants. Private household customers' implicit willingness to pay for certain attribute levels can be estimated based on these results.

\subsection{Estimation of hierarchical Bayes model}

\subsubsection{Estimation of utility values of attribute levels of electricity products}

Table 2 summarizes the results from the choice experiments with the mean utility values of the estimated hierarchical Bayes model as well as the corresponding standard deviations. A utility value describes the influence that a change in one of the attribute levels has on the total utility of a product. Except for the price attribute (monthly electricity costs), they are expressed as zerocentered part-worth utilities, which means that positive values represent an increase in utility relative to the average level of that particular attribute, and negative values represent a decreasing utility. The effect of overall monthly electricity costs was estimated as a single linear utility parameter. Generally, utility values are dependent on the selected range of attribute levels and should thus primarily be used to compare the part-worth utilities of different levels of a given attribute. Comparisons across attributes are facilitated by converting part-worth utilities to willingness to pay (see section below), which implies the advantage of canceling out the scale effect (e.g. Louviere et al., 2008). The standard deviation from the mean of the average utility values shows the variance of the individual preferences. The larger the standard deviations are in comparison to the difference between the maximum and the minimum utility value of the given attribute, the more the preferences of the individual respondents differ regarding the respective attribute level.

\subsubsection{Importance of attributes}

The different attributes have varying levels of influence on electricity customers' product choices. The importance of an attribute reflects its contribution to the utility of the product. In order to calculate the importance of each attribute, we divided the difference in utility between the highest and lowest attribute level for this particular attribute by the sum of these differences for all seven attributes. The mean of these ratios for each respondent represents the importance of the attributes. Thus it is clear that the derived importances are dependent on the selection of the attributes and the definition of the attribute levels. For example, framing costs in terms of monthly expenditures as in this study may decrease the importance of cost in comparison to an aggregate framing of costs such as costs per year (Kaenzig and Wüstenhagen, 2010; Kaenzig, 2010).

In Table 3, the different product attribute importances are listed in descending order. We used two ways to assess attribute 
Table 2

Hierarchical Bayes ${ }^{\mathrm{a}}$ model estimation of mean utility values ${ }^{\mathrm{b}}(N=4968$ choices made by 414 survey participants).

\begin{tabular}{|c|c|c|}
\hline Hierarchical Bayes model & Mean & Standard deviation \\
\hline \multicolumn{3}{|l|}{ Electricity mix ${ }^{\mathrm{c}}$} \\
\hline Mix 1 (60\%C, 25\%N, 15\%?) & -3.98 & $(3.52)$ \\
\hline Mix 2 (60\%C, 25\%N, 5\%H, 5\%W, 5\%B) & -2.20 & $(2.40)$ \\
\hline Mix 3 (60\%C, 25\%G, 5\%H, 5\%W, 5\%B) & 0.30 & $(1.36)$ \\
\hline Mix 4 (50\%W, 30\%H, 15\%B, 5\%S) & 2.85 & $(2.99)$ \\
\hline Mix $5(100 \% \mathrm{~W})$ & 3.03 & $(3.40)$ \\
\hline Max. difference in part-worth2 (max.-min.) & 7.01 & \\
\hline \multicolumn{3}{|l|}{ Power provider } \\
\hline Big, national provider & -0.18 & $(0.47)$ \\
\hline Specialized provider & -0.04 & $(0.59)$ \\
\hline Middle-sized, regional provider & 0.06 & $(0.59)$ \\
\hline Municipal & 0.16 & $(0.65)$ \\
\hline Max. difference in part-worth2 (max.-min.) & 0.34 & \\
\hline \multicolumn{3}{|l|}{ Location of electricity generation } \\
\hline In Eastern Europe & -1.38 & $(1.19)$ \\
\hline In Switzerland & -0.50 & $(0.97)$ \\
\hline In Germany & 0.93 & $(0.95)$ \\
\hline In the region & 0.95 & $(0.95)$ \\
\hline Max. difference in part-worth2 (max.-min.) & 2.33 & \\
\hline \multicolumn{3}{|l|}{ Certification } \\
\hline No certification & -0.39 & $(0.67)$ \\
\hline ok power & 0.03 & $(0.51)$ \\
\hline TÜV & 0.12 & $(0.53)$ \\
\hline Grüner Strom Label & 0.24 & $(0.50)$ \\
\hline Max. difference in part-worth2 (max.-min.) & 0.62 & \\
\hline \multicolumn{3}{|l|}{ Price guarantee } \\
\hline None & -0.74 & $(0.71)$ \\
\hline 6 months & 0.01 & $(0.57)$ \\
\hline 12 months & 0.28 & $(0.61)$ \\
\hline 24 months & 0.45 & $(0.70)$ \\
\hline Max. difference in part-worth2 (max.-min.) & 1.19 & \\
\hline \multicolumn{3}{|l|}{ Cancellation period } \\
\hline Yearly & -0.16 & $(0.60)$ \\
\hline Semi-yearly & -0.05 & $(0.58)$ \\
\hline Quarterly & 0.02 & $(0.55)$ \\
\hline Monthly & 0.19 & $(0.63)$ \\
\hline Max. difference in part-worth2 (max.-min.) & 0.35 & \\
\hline Monthly electricity costs ${ }^{\mathrm{d}}$ & -0.38 & $(0.21)$ \\
\hline None (would not buy) & 3.84 & $(4.57)$ \\
\hline
\end{tabular}

a The hierarchical Bayes method allows for the estimation of individual utility values for every respondent and thus allows considering heterogeneous preferences. The average root likelihood, which is the geometric mean of the predicted probabilities, is 0.72 . This relatively large value indicates a good fit of the model. If the effects were all zero this value would be one third, as there are three alternatives in each choice task. The average root likelihood would be one if the fit were perfect.

${ }^{b}$ Mean utilities can best be compared within one attribute. Mean utilities are bolded and average standard deviations are shown in parentheses.

' $C=$ Coal; $G=$ Natural gas; $N=$ Nuclear power; $H=$ Hydropower; $W=$ Wind; $B=$ Biomass; $S=$ Solar; ?=Unknown origin.

${ }^{\mathrm{d}}$ Calculating separate utility values for each cost level we verified that they are effectively linearly related to costs.

importances, presented in two columns in the table below: the hierarchical Bayes model indirectly computes average importance based on individual-level responses to the choice tasks. For comparison, we also included a direct query asking for a self-assessment of respondents with regard to the importance of attributes.

When directly asked to assess the importance of attributes for their choices, respondents tend to put a particular emphasis on attributes related to price (monthly electricity cost and price guarantee). This finding is less pronounced but corroborates the results of studies conducted in North America and Great Britain (Promit, 2004; Rowlands et al., 2004; Watson et al., 2002), in which private household customers assigned the price of electricity greater importance than the electricity mix and the environmental
Table 3

Importances of the attributes of electricity products.

\begin{tabular}{|c|c|c|c|c|}
\hline \multirow[t]{2}{*}{ Attribute } & \multicolumn{2}{|c|}{ Entire sample $(N=414)$} & \multicolumn{2}{|c|}{$\begin{array}{l}\text { Green power customers } \\
(N=29)\end{array}$} \\
\hline & $\begin{array}{l}\text { Hierarchical } \\
\text { Bayes (\%) }\end{array}$ & $\begin{array}{l}\text { Direct } \\
\text { query }\end{array}$ & $\begin{array}{l}\text { Hierarchical } \\
\text { Bayes (\%) }\end{array}$ & $\begin{array}{l}\text { Direct } \\
\text { query }\end{array}$ \\
\hline $\begin{array}{l}\text { Monthly electricity } \\
\text { costs }\end{array}$ & 30 & 1.5 & 23 & 1.6 \\
\hline Electricity mix & 32 & 3.3 & 49 & 1.6 \\
\hline $\begin{array}{l}\text { Location of electricity } \\
\text { generation }\end{array}$ & 13 & 3.4 & 9 & 3.0 \\
\hline Price guarantee & 8 & 1.8 & 5 & 2.0 \\
\hline Certification & 6 & 3.6 & 4 & 2.4 \\
\hline Power provider & 6 & 3.3 & 5 & 2.8 \\
\hline Cancellation period & 6 & 2.7 & 4 & 3.1 \\
\hline
\end{tabular}

Direct query: 6-point Likert scale: 1 very important; 6: not important.

and energy supply security issues associated with it. A strong emphasis on price is not unusual in the context of lowinvolvement products where people tend not to have strong preferences for product attributes, and where the value proposition of products priced at a premium may not be immediately clear (Litvine and Wüstenhagen, 2011). However, based on the conjoint analysis data, a more nuanced picture of customer preferences emerges. The hierarchical Bayes model confirms a high importance of price, but suggests that electricity mix is equally important in explaining people's choices. It also suggests that contract terms such as price guarantee and cancellation period may actually be of lower importance in explaining consumer choice than respondents think when being asked directly. Both methods suggest that type of power provider and certification were relatively less important attributes at the time of conducting the survey. As for certification, this may partly be due to the relatively low level of familiarity of eco-labels for electricity. As a matter of fact, only $22 \%$ of the survey respondents have heard about the label "Grüner Strom Label" and less than $5 \%$ of the respondents have heard about the label "ok power". Finally, $35 \%$ of the respondents have heard about the "TÜV" label. However, the somewhat higher awareness rate of the TÜV label can be explained by the fact that TÜV is an umbrella label commonly used for the validation of the safety of many product categories in Germany, including motor vehicles. We cannot fully exclude the possibility that the disclosure of detailed information on the electricity mix, as in these choice experiments, might have a diminishing influence on the importance of certification. There are also differences in the importance of labels between green power customers and other respondents. In the direct query, where no detailed information on the electricity mix was shown to respondents, the certification gets more importance among green power customers, while its importance remains low for the entire sample.

Our empirical evidence on the relatively low importance of certification in explaining consumer choice in the German electricity market should be interpreted with care. While the development of solid certification schemes for electricity products may not pay off in the short term, it may be an important long-term investment in the credibility of the green electricity market. The influence of eco-labels could significantly increase when a higher share of customers gets to know them and appreciates them as trusted signals of environmental product quality. Credible ecolabels can both play an important supporting role when communicating with environmentally-conscious customers or critical stakeholders, as well as help with quality assurance (Markard and Truffer, 2006; Truffer et al., 2001). In other product categories, such as organic food and household appliances, environmental labels have been shown to significantly affect consumer choice (Janssen and Hamm, 2012; Ward et al., 2011; Murray and 
Mills, 2011; Sammer and Wüstenhagen, 2006). Additionally, they can have an important indirect influence on the product range offered (Rubik et al., 2007; Heinzle and Wüstenhagen, 2012). Increasing transparency by providing comparable information on the electricity consumption of electric appliances for instance has considerably increased energy-efficiency of refrigerators within a few years (IEA, 2003).

In addition, Table 3 also compares attribute importances of the entire sample to attribute importances chosen by green power customers. Only $7 \%$ of electricity customers of the representative sample are green power customers. This confirms, that the reported WTP is not reflected in actual market shares of green electricity products. Unsurprisingly, those customers who are already purchasing green power attach more importance to the attribute electricity mix and less importance to price than the average respondent.

\subsubsection{Willingness to pay for attribute levels of electricity products}

Fig. 2 shows the results of the hierarchical Bayes model expressed as the median respondent's implicit willingness-topay (WTP), which indicates an upper boundary of the amount the respondent would be willing to pay in exchange for an upgrade in the level of a particular attribute. WTP is calculated as presented in the following: we estimated the effect of monthly electricity costs as a linear coefficient based on individual preferences. By dividing the difference in part-worth utilities for the levels of other attributes by this cost coefficient, we obtain an estimate of implicit WTP. WTP between the default and the other attribute levels were measured by dividing the difference in estimated utilities of those two attribute levels by the cost coefficient. We calculate individual respondents' implicit WTP for a change from one attribute level to another by using the following formula:

$\mathrm{WTP}_{\text {change }}=\left(\frac{\beta_{i 1}-\beta_{i 2}}{\beta_{\text {price }}}\right)$ where $\beta_{i 1}$ indicates the part-worth utility value per attribute level $i 1$ and $\beta_{i 2}$ indicates the part-worth utility value per attribute level $i 2, \beta_{\text {price }}$ is the linear coefficient for the attribute monthly electricity costs. The median is reported in Fig. 2.

To facilitate interpretation of results, we express WTP relative to a default (Mix 2, made in Germany, regional provider, no price guarantee, no certification, yearly cancellation period) here, rather than as zero-centered part-worth utilities as in Table 2 above. It is important to note that the purpose of this paper is not primarily to come up with a precise measure of willingness-topay for green electricity, but to present a joint test for the importance of different attributes and levels in explaining consumer choices in the electricity market, especially relative to current defaults. When interpreting these results and especially the specific values for WTP, it should be kept in mind that the answers to questions involving environmental issues can be subject to social desirability biases (Diekmann, 2006) and that there is a specialized stream of literature about the gap between hypothetical and real WTP (see for example Ladenburg and Olsen, 2010; List et al., 2006). While the indirect measurement of WTP in a conjoint experiment has some advantages over direct elicitation of WTP with regard to overcoming social desirability, our results are still based on an experimental setting and respondents did not actually have to pay the price that they indicated they would accept in their product choice. Finally, actual WTP in a real-life market setting may depend on unobserved factors, such as the status quo effect discussed above or the transaction cost of switching electricity providers. Therefore, the absolute values presented here should be interpreted as upper boundaries of WTP and used with care.

Fig. 2 highlights that apart from monthly electricity costs, the attributes electricity mix and location of electricity generation have the strongest influence on customer choices. Electricity mixes with renewable energy are favored over those containing high shares of non-renewable energy sources. This is shown by the low preference for Mix 1 (60\% coal, 25\% nuclear power, 15\% from unknown origin)

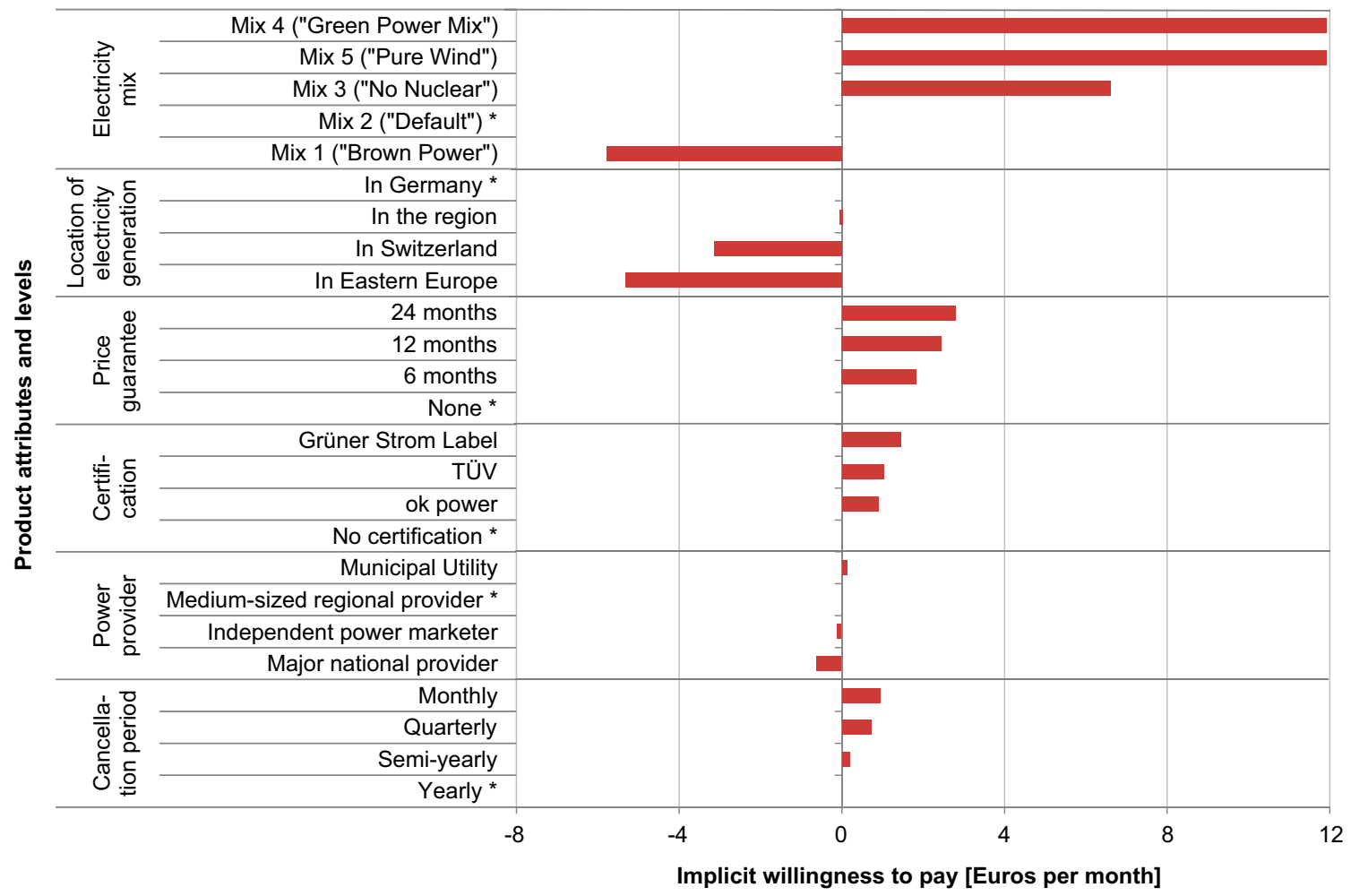

Fig. 2. Implicit willingness to pay for attribute levels of electricity products (relative to default). Note: Attribute levels of default product (Mix 2, made in Germany, regional provider, no price guarantee, no certification, yearly cancellation period) are marked with an asterisk. 


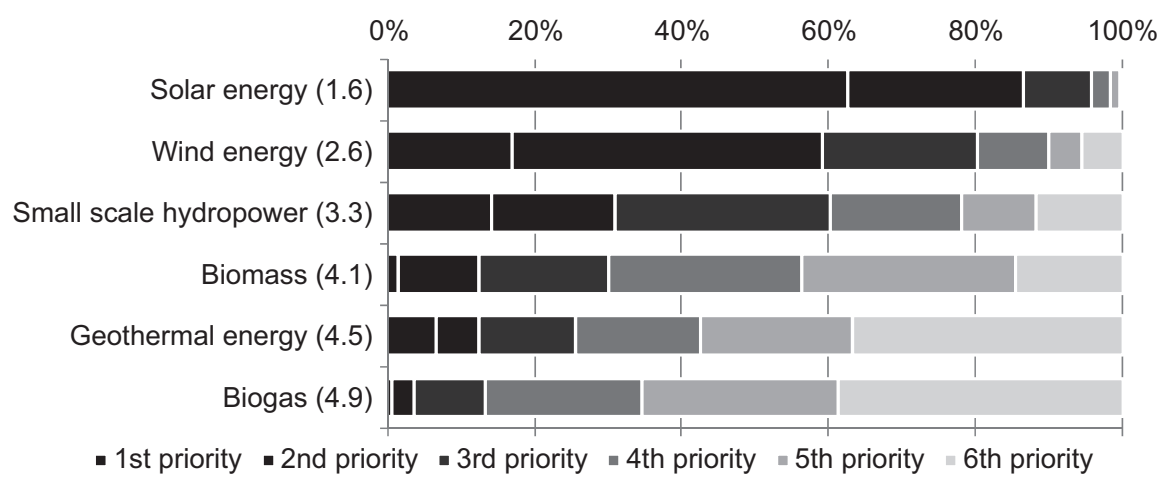

Fig. 3. Ranking of preferences for the support of renewable energy sources (The values in parentheses represent the average ranking in the respondents' priority lists).

and Mix 2 (60\% coal, 25\% nuclear power, 5\% water, 5\% wind, 5\% solar energy). These low levels of preference for energy mixes with no or low share of renewable energy can then be compared to the substantially higher preference for green power in both Mix 4 (50\% wind, 30\% water, $15 \%$ biomass, $5 \%$ solar) and Mix 5 (100\% wind power). Relative to the default and all else being equal, switching to Mix 1 reduces WTP by about 6 Euros per month, while switching to the green power mixes 4 and 5 increases WTP by about 12 Euros per month, or about $16 \%$ of average household electricity $\operatorname{cost}^{3}$, respectively. Simply replacing the existing share of nuclear by natural gas as in Mix 3 still results in a positive WTP of about 7 Euros per month. The significance of the differences between these WTP figures was tested using a non-parametric test, that is, the Mann-Whitney $U$-test. The implicit WTP for the two green power mixes (Mix 4 and Mix 5) is significantly different from the implicit WTP for the nuclear free Mix 3 and the price discount respondents implicitly demanded for choosing Mix $1(p<0.05)$. However, we found no significant difference between the implicit WTP for the green power Mix 4 and the implicit WTP for pure wind power (Mix 5$)(p=0.86)$. With regard to the location of electricity generation, there is clearly a higher preference for electricity produced in the own region or in Germany as opposed to electricity imported from abroad. A possible explanation may be that customers associate domestic power with a higher level of energy supply security. The average part-worth utilities for electricity from municipal utilities and medium-sized regional providers are higher than that for electricity from major national providers or independent power marketers. However, the differences are very small compared to other attributes. The same is true for preferences with regard to different forms of green power certification. The green power label "Grüner Strom Label" was able to attract a slightly higher part-worth utility level than the $T \ddot{U} V$ and the ok power label, and a product certified against any of those standards caused a small but not significant increase in WTP compared to a product without certification.

Among the two attributes reflecting contract terms, the attribute contract length had a minor influence on product choice. In contrast, a long-term price guarantee creates some positive customer value, which is not surprising considering the recent trend of rising prices in the German electricity market. The implicit WTP for a 24-month price guarantee is about 3 Euros per month.

\subsection{Detailed preferences for renewable energy sources}

Besides the choice experiments presented in the section above, the survey also included a set of descriptive questions. Several

\footnotetext{
${ }^{3}$ Based on an average residential electricity price of $24.95 \mathrm{ct} / \mathrm{kWh}$ and an average annual consumption of $3500 \mathrm{kWh} / \mathrm{a}$ per household, which translates into average monthly electricity cost of $73 €$.
}

interesting findings relevant to the design of electricity products can be found in the results from this section. For example, many green power labels stipulate that a portion of the price premium must be invested in a fund to support the development of new renewable energy capacity. In the present study, the respondents were asked which types of renewable energy sources they think should be supported by such green power funds. The respondents were asked to rank the different types of renewable energy sources according to their preferences in order from 1 (favorite) to 6 (least favored). The results are presented in Fig. 3.

Solar power receives by far the most goodwill of all the renewable energy sources, confirming the results of various other studies (Borchers et al., 2007; Burkhalter et al., 2009; Farhar, 1999). Ranking second and third, after quite a gap, are wind power and small hydropower plants, respectively. Geothermal energy ranked fifth in the survey. In the case of geothermal and biogas, it is notable that a relatively high portion of the respondents ranked these energy sources as their sixth, and thus least preferred options.

By asking the respondents which energy sources they associate with the terms environmental protection, climate protection, acceptance by the public, job creation, independence from foreign countries, security of supply, landscape destruction and safety risk, we investigated some of the underlying motivation for preferences for specific energy sources.

Fig. 4 shows that renewable energy sources are largely associated to positively loaded terms such as environmental and climate protection, acceptance by the public, job creation and independence from foreign countries. Interestingly, more than half of the respondents associate "security of supply" with either solar, wind or hydro, while only around $15 \%$ each think of either nuclear or coal in that context. Over $85 \%$ of the respondents associated nuclear power with safety risks even before the Fukushima accident. Landscape destruction is associated to nuclear, coal and wind power, all with a share of about $30 \%$ of respondents.

\section{Discussion and conclusions}

\subsection{Key findings and implications}

A central finding of this study is that there is a remarkable gap between customer preferences and the products being offered as the average electricity mix in Germany, mirroring a similar gap that has been identified in a study in Switzerland (Burkhalter et al., 2009). With regard to five alternative electricity production mixes offered, the current default ranked second to last in terms of customer preferences. The preference customers expressed for renewable energy products contrasts with the strategies of major 


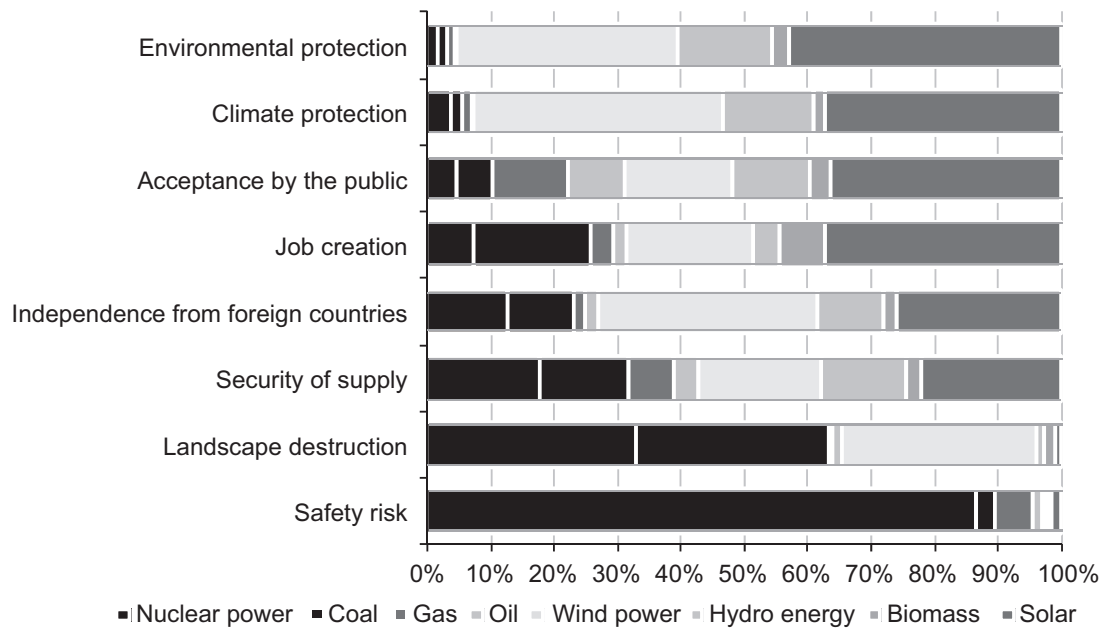

Fig. 4. Association of energy sources with different statements.

electric utilities that, at the time of the survey in 2009, seemed to see the expansion of nuclear power capacity or at least a lifetime extension of existing nuclear power plants as part of the solution to future energy problems. Our central hypothesis, "costumers are willing to pay a significant price premium for an upgrade from the current default electricity mix in Germany to a more environmentally friendly electricity mix", can be confirmed for Germany and based on Burkhalter et al. (2009) also for Switzerland.

This has significant implications for marketing strategy and energy policy. As for incumbent utilities, our results demonstrate that they can create real customer value by shifting their supply mix towards a higher share of renewables, as long as price premiums remain below WTP. For policy makers, findings like the study presented in this paper may provide a legitimate basis for mandating "green defaults", i.e. standard electricity offerings based on a higher share of renewable energy and priced at a modest premium. This may be particularly relevant in the case of municipal utilities with public ownership. On the other hand, independent power marketers may see our results as confirmation for the substantial market potential for green power. New competitors may exploit the gap between customer preferences and the product portfolio and corporate strategy of some incumbents-provided that they manage to overcome inertia in the market and the power of status quo.

With regard to other attributes, the German consumers we surveyed expressed a clear preference for domestically-generated power. Price guarantee and contract length proved to be of lower importance at the time of the study. The current study also shows that certification with one of the three eco-labels included in our survey had a rather low importance for German costumers. Green power marketers can conclude that information on the electricity generation mix is of highest importance. If that information is provided in a similarly detailed and transparent manner as in our survey, then it seems to supersede the potential signaling effect of a green power certification scheme. Yet, as detailed in Section 5.1.2 above, it should also be mentioned that eco-labels, can play an important supporting role in the longer term to secure the credibility of green power products. The value of eco-labels for electricity products may for example be recognized by customers and suppliers if the media were to critically address the environmental performance of electricity products.

Finally, our findings about detailed preferences for different energy sources also lead to specific implications for product design. Including some solar power content in certified electricity products will allow to position such products at the higher end of the product (and price) range, while wind power and hydropower, viewed less favorably than solar by customers, will not add as much value to premium products. The relatively low preference ranking for biogas and biomass compared to other renewables suggests that marketing communication for a green power mix containing biomass would be well advised to create a link to one of the preferred product attributes, such as the local availability of the resource.

\subsection{Limitations and further research}

As any piece of research, this study is subject to some limitations that can serve as starting points for further research.

As for any stated preference survey, one limitation of our study is that there may be a gap between stated and revealed preferences. We have taken important steps to limit potential biases by surveying a large sample of real electricity customers, by soliciting discrete choices rather than directly asking for preferences for individual attributes, and by carefully crafting a realistic choice situation. Because the choice object was essentially a private good (electricity product) with some public good component (positive environmental externalities of renewable energy content), we believe that some of the hypothetical bias that may be present in other applications of conjoint measurement in the energy and resource economics literature, and in contingent valuation studies to measure WTP for purely public goods, is less pronounced here. Nevertheless, some of the approaches developed in these streams of literature to alleviate hypothetical bias, such as "cheap talk" and opt-out reminders (Ladenburg and Olsen, 2010; List et al., 2006), could be beneficial in further research on customer preferences for green electricity. It may also be worth exploring approaches developed in the marketing literature, such as incentive-aligned choice based conjoint analysis (ICBC, Ding, 2007), where hypothetical choices are combined with experimental purchasing decisions by respondents. In their review of such more sophisticated approaches, Miller et al. (2011) caution, however, that while simple discrete choice experiments may lead to some hypothetical bias, this does not necessarily compromise their ability to provide valid guidance for real-life product design and pricing decisions.

In any case, willingness to pay can be overestimated in choice experiments (Byrnes et al., 1999). Estimated WTP figures may serve as an illustration of the relative ranking of attribute levels and preferences, and can be interpreted as an upper boundary of what consumers would actively decide to pay in a real market setting. Factors like transaction cost, lack of awareness, availability of products, customer inertia, social and competitive 
influences, need to be taken into account when interpreting the data. Future studies may attempt to address these factors by calibrating stated WTP with revealed preferences (market data).

We used the average German electricity mix as a proxy for the default product. Further research could relax this constraint by gathering data on individual-level electricity choices, ideally including detailed data about attributes of the previous electricity contract, the chosen alternative as well as the shortlist (evoked set) of considered competitive offerings. To overcome data availability issues, such a comprehensive analysis of revealed preferences would probably have to be done using online data on customer choices from utilities, power marketers or internet portals for electricity.

Our results relate to an average electricity consumer. A significant premium, however, does not imply that all consumers are willing to pay a premium for green electricity. There is evidence in the scientific literature showing that the premium customers are willing to pay differ across customer segments (Grösche and Schröder, 2011). Our findings can be the basis for future research refining the assessment of the factors influencing the willingness to pay of specific consumer segments for green electricity.

Finally, the study presented in this paper was limited to Germany. While our findings were in line with a similar study conducted in Switzerland (Burkhalter et al., 2009), further research could test our hypothesis in different geographical settings and explore whether aspects like competitive market structures, cultural factors or different default products influence the results. The rising awareness for energy issues in the aftermath of the Fukushima nuclear accident in 2011 may provide a fruitful environment for further research on shifting customer preferences in many countries.

\section{Acknowledgments}

This paper is based on research funded by the German Ministry of Education and Research, within the Program "SocioEcological Research (SÖF)", project "Social, environmental and economic dimensions of sustainable energy consumption in residential buildings (seco@home)", Contract no. 01UV0710, coordinated by Dr. Klaus Rennings at the Center for European Economic Research (ZEW), Mannheim. The authors wish to acknowledge valuable support and feedback from the seco@home project team and advisory board, as well as extensive comments received from three anonymous reviewers. All remaining errors are the sole responsibility of the authors.

\section{Appendix}

See Table A1.

Table A1

Demographic characteristics of the sample $(\boldsymbol{N}=414)$ compared to the structure of the German population (in brackets the results from a Chi-square test indicating whether the sample is significantly different from the German average).

\begin{tabular}{|c|c|c|c|c|c|}
\hline Characteristics & $\begin{array}{l}\text { Survey } \\
(\%)\end{array}$ & $\begin{array}{l}\text { German average } \\
(\%)\end{array}$ & Characteristics & $\begin{array}{l}\text { Survey } \\
(\%)\end{array}$ & $\begin{array}{l}\text { German } \\
\text { average } \\
(\%)^{\mathrm{a}}\end{array}$ \\
\hline \multicolumn{3}{|l|}{ Gender $\left(\chi^{2}=1.933\right.$, d.f. $\left.=1, p=0.164\right)$} & \multicolumn{3}{|l|}{ State $(\chi 2=6.296$, d.f. $=3, p=0.098)$} \\
\hline Female & 47.6 & 51.0 & Northern Region (Bremen, Hamburg, & 19.3 & 16.1 \\
\hline Male & 52.4 & 49.0 & Lower Saxony, Schleswig-Holstein) & & \\
\hline \multicolumn{3}{|l|}{ Age $(\chi 2=85.692 .$, d.f. $=4, p<0.001)$} & \multirow{7}{*}{$\begin{array}{l}\text { Eastern region (Mecklenburg-Western } \\
\text { Pomerania, Brandenburg, } \\
\text { Berlin, Saxony, Saxony-Anhalt, } \\
\text { Thuringia) }\end{array}$} & \multirow[t]{7}{*}{22.7} & \multirow[t]{7}{*}{20.1} \\
\hline $15-24$ yrs & 2.7 & 13.4 & & & \\
\hline $25-39$ yrs & 19.6 & 22.1 & & & \\
\hline $40-59$ yrs & 53.1 & 35.1 & & & \\
\hline $60-64$ yrs & 7.5 & 6.0 & & & \\
\hline 65 yrs and older & 16.4 & 23.3 & & & \\
\hline Not specified & 0.7 & & & & \\
\hline \multicolumn{3}{|c|}{ Highest level of education $(\chi 2=51.498$, d.f. $=5, p<0.001)$} & \multirow{5}{*}{$\begin{array}{l}\text { Western region (North Rhine- } \\
\text { Westphalia, Hesse, } \\
\text { Rhineland-Palatinate, Saarland) }\end{array}$} & \multirow[t]{5}{*}{31.9} & \multirow[t]{5}{*}{35.4} \\
\hline None & 1.0 & 3.9 & & & \\
\hline Elem./sec. school & 35.7 & 39.3 & & & \\
\hline General certificate & 32.9 & 21.1 & & & \\
\hline Polytechnic inst. & 6.8 & 6.6 & & & \\
\hline Technical college/Abitur or higher & 23.3 & 24.4 & Southern region (Bavaria, Baden- & 26.1 & 28.4 \\
\hline Not specified & 0.2 & 3.9 & Württemberg) & & \\
\hline \multicolumn{3}{|c|}{ Monthly net income of household $\left(\chi^{2}=5.897, d . f .=4, p=0.207\right)$} & \multicolumn{3}{|l|}{ City size $(\chi 2=2.432$, d.f. $=3, p=0.488)$} \\
\hline Under $€ 1500$ & 30.7 & 35.0 & $n=1-19,999$ & 39.1 & 41.8 \\
\hline$€ 1500-€ 1999$ & 17.6 & 15.6 & $n=20,000-99,999$ & 30.0 & 27.4 \\
\hline$€ 2000-€ 2499 / € 2599$ & 15.7 & 14.4 & $n=100,000-499,999$ & 16.2 & 15.0 \\
\hline Over $€ 2500 / € 2600$ & 26.6 & 27.3 & $n>500,000$ & 14.7 & 15.9 \\
\hline Not specified & 9.4 & 7.5 & & & \\
\hline \multicolumn{3}{|l|}{ Civil status $(\chi 2=1.575$, d.f. $=1, p=0.210)$} & \multicolumn{3}{|c|}{ Household size $(\alpha 2=0.537$, d.f. $=4, p=0.970)$} \\
\hline Married & 46.9 & 43.8 & 1 & 38.4 & 39.4 \\
\hline \multirow[t]{2}{*}{ Unmarried } & 53.1 & 56.2 & 2 & 34.3 & 34.0 \\
\hline & & & 3 & 12.8 & 13.1 \\
\hline \multirow{2}{*}{\multicolumn{3}{|c|}{ Property ownership situation $(\chi 2=0.024$, d.f. $=1, p=0.878)$}} & 4 & 10.4 & 9.9 \\
\hline & & & $5+$ & 4.1 & 3.6 \\
\hline Property owner & 46.4 & 46.0 & & & \\
\hline Renter & 53.6 & 54.0 & & & \\
\hline
\end{tabular}

\footnotetext{
a German federal statistics office (2009a, 2009b, 2009c).
} 


\section{References}

Allenby, G.M., Bakken, D.O., Rossi, P.E., 2004. The HB revolution-How Bayesian methods have changed the face of marketing research. Marketing Research $16,20-25$

Anderson, C.J., 2003. The psychology of doing nothing: forms of decision avoidance result from reason and emotion. Psychological Bulletin 129, 139-167.

Ben-Akiva, M., Bradley, M., Morikawa, T., Benjamin, J., Novak, T., Oppewal, H., Rao, V., 1994. Combining revealed and stated preferences data. Marketing Letters 5 (4), 335-350.

Bird, L., Wüstenhagen, R., Aabakken, J., 2002. A review of international green power markets: recent experience, trends, and market drivers. Renewable and Sustainable Energy Reviews 6, 513-536.

Borchers, A.M., Duke, J.M., Parsons, G.R., 2007. Does willingness to pay for green energy differ by source? Energy Policy 35, 3327-3334.

Brown, C.L., Krishna, A., 2004. The skeptical shopper: a metacognitive account for the effects of default options on choice. Journal of Consumer Research 31, 529-539.

Burkhalter, A., Kaenzig, J., Wüstenhagen, R., 2009. Kundenpräferenzen für leistungsrelevante Attribute von Stromprodukten. Zeitschrift für Energiewirtschaft 33, 161-172.

Byrnes, B., Jones, C., Goodman, S., 1999. Contingent valuation and real economic commitment: evidence from electric utility green pricing programmes. Journal of Environmental Planning and Management 42, 149-166.

Diekmann, A., 2006. Empirische Sozialforschung-Grundlagen, Methoden, Anwendungen, Rowohlt, Reinbek bei Hamburg.

Ding, M., 2007. An incentive-aligned mechanism for conjoint analysis. Journal of Marketing Research 44 (5), 214-223.

Energie and Management, 2010. 6. E\&M-Ökostromumfrage. Energie and Management. Verlagsgesellschaft mbH, Herrsching.

Farhar, B.C., 1999. Willingness to Pay for Electricity from Renewable Resources: A Review of Utility Market Research. National Renewable Energy Laboratory, Golden, CO.

García-Acebrón, C., Vázquez-Casielles, R., Iglesias, V., 2010. The effect of perceived value and switching barriers on customer price tolerance in industrial energy markets. Journal of Business-to-Business Marketing 17 (4), 317-335.

German Federal Statistics Office, 2009a. Statistisches Jahrbuch. Kapitel Bevölkerung. Federal Statistics Office, Wiesbaden.

German Federal Statistics Office, 2009b. Auszug aus dem Datenreport 2008. Kapitel 2: Familie, Lebensformen und Kinder. Federal Statistics Office, Wiesbaden.

German Federal Statistics Office, 2009c. Bildungsstand der Bevölkerung. Federal Statistics Office, Wiesbaden.

Gerpott, T.J., Mahmudova, I., 2009. Einflussfaktoren auf die Bereitschaft von Privatkunden, Ökostrom nachzufragen-Ergebnisse einer empirischen Untersuchung. Zeitschrift für Energiewirtschaft 33, 316-321.

Goett, A.A., Hudson, K., Train, K.E., 2000. Customer's choice among retail energy suppliers: the willingness-to-pay for service attributes. The Energy Journal 21, $1-28$.

Goldstein, D.G., Johnson, E.J., Herrmann, A., Heitmann, M., 2008. Nudge your customers toward better choices. Harvard Business Review 86, 99-105.

Graf, P., 2012. Ökologische Stromtarifrevision. [Introduction of Green Electricity Defaults]. In: Proceedings of the Presentation held at the 3rd St. Gallen Forum for Management of Renewable Energies, May 25, 2012. Available from: $\langle$ http://forum.iwoe.unisg.ch $\rangle$.

Grösche, P., Schröder, C., 2012. Eliciting public support for greening the electricity mix using random parameter techniques. Energy Economics 33 (2) 363-370.

Gustafsson, A. Herrmann, A., Huber, F. (Eds.), 2007. Conjoint Measurement: Methods and Applications, fourth ed. Springer, Berlin.

Hansla, A., 2011. Value orientation and framing as determinants of stated willingness to pay for eco-labeled electricity. Energy Efficiency 4 (2), 185-192.

Hartmann, P., Apaolaza-Ibáñez, V., 2007. Managing customer loyalty in liberalized residential energy markets: the impact of energy branding. Energy Policy $35,2661-2672$.

Heinzle, S., Wüstenhagen, R., 2012. Dynamic adjustment of eco-labeling schemes and consumer choice - the revision of the EU energy label as a missed opportunity? Business Strategy and the Environment 21 (1), 60-70.

Herrmann, A., Landwehr, J.R., Henneberg, S., Morgan, R., 2009. Consumer decision making under variety: the effect of attribute alignability. Psychology \& Marketing 26, 333-358.

Huber, J., Train, K., 2001. On the similarity of classical and Bayesian estimates of individual mean partworths. Marketing Letters 12, 259-269.

IEA, 2003. Cool Appliances-Policy Strategies for Energy Efficient Homes. International Energy Agency, Paris.

Janssen, M., Hamm, U., 2012. Product labelling in the market for organic food: consumer preferences and willingness-to-pay for different organic certification logos. Food Quality and Preference 25 (1), 9-22.

Johnson, E.J., Goldstein, D.G., 2003. Do defaults save lives? Science 302, 1338-1339.

Johnson, R.M., 2000. Understanding HB: An Intuitive Approach. Sawtooth Software Inc., Sequim, WA.

Kahneman, D., Knetsch, J.L., Thaler, R.H., 1991. The endowment effect, loss aversion and status quo bias. Journal of Economic Perspectives 5, 193-206.

Kaenzig, J., Wüstenhagen, R., 2008. Understanding the green energy consumer. Marketing Review St. Gallen 25, 12-16.
Kaenzig, J., Wüstenhagen, R., 2010. The effect of life cycle cost information on consumer investment decisions regarding eco-innovation. Journal of Industrial Ecology 14, 121-136.

Kaenzig, J., 2010. Intertemporal Choices regarding Sustainable Energy Consumption-Conceptual and Experimental Insights from the Residential Sector. Thesis. Difo-Druck, St. Gallen.

Ladenburg, J., Olsen, S.B., 2010. Augmenting Short Cheap Talk Scripts With a Repeated Opt-Out Reminder in Choice Experiment Surveys. FOI Working Paper, No. 9. Institute of Food and Resource Economics, University of Copenhagen.

List, J.A. Sinha, P., Taylor, M.H., 2006. Using choice experiments to value nonmarket goods and services: evidence from field experiments. Advances in Economic Analysis and Policy 6 (2), 1-37. (Article 2).

Litvine, D., Wüstenhagen, R., 2011. Helping "light green" consumers walk the talk: results of a behavioral intervention survey in the Swiss electricity market. Ecological Economics 70 (3), 462-474.

Louviere, J.J., Hensher, D.A., Swait, J.D., 2003. Stated Choice Methods: Analysis and Applications, second ed. Cambridge University Press, Cambridge.

Louviere, J.J., Islam, T., Wasi, N., Street, D., Burgess, L., 2008. Designing discrete choice experiments: do optimal designs come at a price? Journal of Consumer Research 35 (2), 360-375.

Markard, J., Truffer, B., 2006. The promotional impacts of green power products on renewable energy sources: direct and indirect eco-effects. Energy Policy 34, 306-321.

Menegaki, A.N., 2012. A social marketing mix for renewable energy in Europe based on consumer stated preference surveys. Renewable Energy 39 (1), 30-39.

Menges, R., Schröder, C., Traub, S., 2004. Umweltbewusstes Konsumentenverhalten aus ökonomischer Sicht: Eine experimentelle Untersuchung der Zahlungsbereitschaft für Ökostrom. Umweltpsychologie 8, 84-106.

Menges, R., Schröder, C., Traub, S., 2005. Altruism, warm glow and the willingnessto-donate for green electricity: an artefactual field experiment. Environmental \& Resource Economics 31, 431-458.

Mewton, R.T., Cacho, O.J., 2011. Green power voluntary purchases: price elasticity and policy analysis. Energy Policy 39 (1), 377-385

Miller, K.M., Hofstetter, R., Krohmer, H., Zhang, Z.J., 2011. How should consumers' willingness to pay be measured? an empirical comparison of state-of-the-art approaches. Journal of Marketing Research 48 (1), 172-184.

Mozumder, P., Vásquez, W.F., Marathe, A., 2011. Consumers' preference for renewable energy in the southwest USA. Energy Economics 33 (6), 1119-1126.

Mullainathan, S., Thaler, R.H., 2000. Behavioral Economics. NBER Working Paper no. 7948.

Murray, A.G., Mills, B.F., 2011. Read the label! energy star appliance label awareness and uptake among US consumers. Energy Economics 33 (6), 1103-1110.

Netzer, O., Toubia, O., Bradlow, E.T., Dahan, E., Evgeniou, T., Feinberg, F.M., Feit, E.M., Hui, S.K., Johnson, J., Liechty, J.C., Orlin, J.B., Rao, V.R., 2008. Beyond conjoint analysis: advances in preference measurement. Marketing Letters 19, 337-354.

Nomura, N., Akai, M., 2004. Willingness to pay for green electricity in Japan as estimated through contingent valuation method. Applied Energy 78 (4), 453-463.

Oliver, H., Volschenk, J., Smit, E., 2011. Residential consumers in the Cape Peninsula's willingness to pay for premium priced green electricity. Energy Policy 39 (2), 544-550.

Organisation for Economic Co-Operation and Development (OECD), 2008. Global forum on competition, high switching costs: a barrier to competition and a detriment to consumers, London.

Orme, B.K., 2007. Software for Hierarchical Bayes Estimation for CBC Data, CBC/HB v4. Sawtooth Software Inc., Sequim, WA.

Pichert, D., Katsikopoulos, K.V., 2008. Green defaults: information presentation and pro-environmental behavior. Journal of Environmental Psychology 28, 63-73.

Polak, B., Herrmann, A., Heitmann, M., Einhorn, M., 2008. Die Macht des Defaults. Wirkung von Empfehlungen und Vorgaben auf das individuelle Entscheidungsverhalten. Zeitschrift für Betriebswirtschaft 78, 1033-1060.

Promit, 2004. Kundenzufriedenheit bei Haushaltskunden-VDEW Kundenfokus 2004. Frankfurt am Main, Heidelberg.

Revelt, D., Train, K., 1999. Customer-specific taste parameters and mixed logit. Department of Economics, University of California, Berkeley.

Roe, B., Teisl, M.F., Levy, A., Russell, M., 2001. US consumers' willingness to pay for green electricity. Energy Policy 29, 917-925

Rommel, K., Meyerhoff, J., 2009. Empirische Analyse des Wechselverhaltens von Stromkunden. Was hält Stromkunden davon ab, zu Ökostromanbietern zu wechseln? Zeitschrift für Energiewirtschaft 33, 74-82.

Rossi, P.E., Allenby, G.M., 2003. Bayesian statistics and marketing. Marketing Science 22, 304-328

Rossi, P., Allenby, G., McCulloch, R., 2005. Bayesian Statistics and Marketing. Wiley, New York.

Rowlands, I.H., Parker, P., Scott, D., 2004. Consumer behavior in restructured electricity markets. Journal of Consumer Behavior 3, 272-283.

Rubik, F., Frankl, P., Pietroni, L., Scheer, D., 2007. Eco-labelling and consumers: towards a re-focus and integrated approaches. International Journal of Innovation and Sustainable Development 2 (2), 175-191.

Sammer, K., Wüstenhagen, R., 2006. The influence of eco-labelling on consumer behavior-results of a discrete choice analysis for washing machines. Business Strategy and the Environment 15, 185-199. 
Samuelson, W., Zeckhauser, R., 1988. Status bias in decision making. Journal of Risk and Uncertainty 1, 7-59.

Sawtooth Software, 2009. The CBC/HB System for Hierarchical Bayes: Version 5.0. Technical Paper. Sequim, WA.

Scarpa, R., Tiene, M., Train, K., 2008. Utility in willingness to pay space: a tool to address confounding random scale effects in destination choice to the Alps. American Journal of Agricultural Economics 90, 994-1010.

Simon, H., 2008. Betriebswirtschaftliche Wissenschaft und Unternehmenspraxis-Erfahrungen aus dem Marketing-Bereich. Zeitschrift für betriebswirtschaftliche Forschung 60, 73-93.

Sunstein, C.R., Thaler, R.H., 2003. Libertarian paternalism is not an oxymoron University of Chicago Law Review 70, 1159-1202.

Susaeta, A., Lal, P., Alavalapati, J., Mercer, E., 2011. Random preferences towards bioenergy environmental externalities: a case study of woody biomass based electricity in the Southern United States. Energy Economics 33, 1111-1118.
Teichert, T., 2001. Nutzenermittlung in wahlbasierter Conjoint-Analyse: Ein Vergleich zwischen Latent-Class und hierarchischem Bayes-Verfahren. Zeitschrift für betriebswirtschaftliche Forschung 53, 798-822.

Thaler, R., Sunstein, C., 2003. Libertarian paternalism. The American Economic Review 93, 175-179.

Thaler, R., Sunstein, C., 2008. Nudge. Yale University Press, New Haven \& London.

Truffer, B., Markard, J., Wüstenhagen, R., 2001. Eco-labeling of electricity—strategies and tradeoffs in the definition of environmental standards. Energy Policy 29 885-897.

Ward, D.O., Clark, C.D., Jensen, K.L., Yen, S.T., Russell, C.S., 2011. Factors influencing willingness to pay for the Energy Star label. Energy Policy 39, 1450-1458.

Watson, A., Viney, H., Schomaker, P., 2002. Consumer attitudes to utility products: a consumer behavior perspective. Marketing Intelligence and Planning 20, 394-404.

Wüstenhagen, R., Markard, J., Truffer, B., 2003. Diffusion of green power products in Switzerland. Energy Policy 31, 621-632. 